\title{
POLICIES AND IMPLEMENTATION OF WORKER EMPOWERMENT IN CHINESE COMPANIES IN KONAWE DISTRICT, SOUTHEAST SULAWESI PROVINCE
}

\author{
Abubakar ISKANDAR ${ }^{*}$ \\ Djuanda University Bogor, Master's Department of Public Administration, West Java, Indonesia, e-mail: abu1958@yahoo.coma \\ Oetje SUBAGDJA \\ Djuanda University Bogor, Master’s Department of Public Administration, West Java, Indonesia, e-mail: otje.subadgja@unida.ac.id
}

Zahid MUBAROK

Islamic Broadcasting Communication Study Program College of Islamic

Da'wah and Broadcasting, West Java, Indonesia, e-mail: mujahidmujahid2016@gmail.com

\begin{abstract}
Citation: Iskandar, A., Subagdja, O, \& Mubarok, Z. (2021). POLICIES AND IMPLEMENTATION OF WORKER EMPOWERMENT IN CHINESE COMPANIES IN KONAWE DISTRICT, SOUTHEAST SULAWESI PROVINCE. GeoJournal of Tourism and Geosites, 38(4), 1017-1025. https://doi.org/10.30892/gtg.38405-739
\end{abstract}

\begin{abstract}
Based on the Work Plan of the Ministry of Manpower of the Republic of Indonesia, the number of foreign workers entering Indonesia in 2018 were 353,630 workers, causing the Indonesian workers to find job more difficult in their country. The Research Objectives are: (a) To describe policies and implementations to decrease unemployment rates in Southeast Sulawesi Province; (b) To Analyze an expert Chinese Foreign Worker accompanied by ten Indonesian Workers for transfer of knowledge and transfer of jobs; (c) To Identify Chinese Foreign Workers and Indonesian Workers who are employed in Chinese Companies. The research design is a cross sectional design. The sample consisted of 100 people, while the data analysis used flow models, correlation and respondents' perceptions. The results showed that there were 10 Chinese workers and 90 Indonesian workers who worked in a chinese companies, but there are discrimination in different position and payroll system that Chinese workers salary were higher than Indonesian workers.
\end{abstract}

Key words: policy, implementation, workers, science, knowledge, technology, salary

\section{INTRODUCTION}

\section{Background}

The Data on unemployment in Southeast Sulawesi Province showed that in 2020 unemployment rate is $3.17 \%$. This figure has increased from $0.21 \%$ compared to February 2019 and $0.38 \%$ compared to 2018, so $3.17 \%$ has not been absorbed in field. This condition is worst by the increasing foreign workers entered (The Central Bureau of Statistics). Based on the data on the Planned Employment of Foreign Workers of the Ministry of Manpower of the Republic of Indonesia, the number of foreign workers who entered Indonesia in 2018 were 353630 people. This can lead to the marginalization of Indonesian Workers in Foreign Companies in Indonesia, especially the migration of Chinese workers in Konawe Regency, Southeast Sulawesi, every year are 500 people, this causes Indonesian workers to become increasingly narrow in reaching the labor market in Chinese companies in Konawe District Southeast Sulawesi province. Workers are people who are capable of doing work in order to produce goods and / or services both to fulfill their own needs and for the community (Aly, 2003), General Provisions, article 1 paragraph 2. In Law No. 13 In 2003, it was explained that one Chinese Worker accompanied by ten Indonesian Workers, there must be a transfer of knowledge and a transfer of jobs. Therefore, a Chinese Worker is obliged to provide job training to ten Indonesian Workers. Job training is all activities to provide, obtain, improve, and develop work competence, productivity, discipline, attitudes and work ethic at a certain level of skills and expertise in accordance with the level and qualification of a position or job (Aly, 2003), General Provisions, article 1 verse 9. According to (Passed, 2018), there are eight positive and negative impacts of the arrival of foreign workers in Indonesia, as explained below:

Positive impact

1. The new knowledges and technologies in a field of work with the presence of foreign workers, we will get new knowledges in a field of work. We can get these new knowledges from foreign workers who may be commonly practiced in their countries. With these new knowledges that it will increase innovation in Indonesia. Not only new science, but also new technology. Foreign workers bring technology used from their countries to be applied in Indonesia. These will be very beneficial if foreign workers come from developed countries in their fields.

2. The Development of a field work becomes faster the development of field work is strongly supported by qualified and expert human resources. Using foreign workers who are experienced in a particular field can be a good means of development in a field work and this good experience can be passed on to local Indonesian workers.

3. The adoption of new technology become faster. Adoption of technology will be easier if there are workers who are experts in their field works. Technology from developed countries will be easier to do if it is supported by workers who are experienced, especially from the country of the technology.

\footnotetext{
"Corresponding author
} 
4. Increased investment in Indonesia.The presence of foreign workers arriving in Indonesia, it is estimated that there will be an increase in investment in Indonesia. This is also obtained from the results of the recruitment of foreign workers.

5. Increasing the productivity of the local workers. The Competition of foreign workers and local workers will undoubtedly trigger the enthusiasm of local workers to continue to spur themselves so that they can survive in the competition.

Those are some of the positive impacts regarding the entry of foreign workers into the territory of Indonesia. Beside the positive impacts, there are also be negative impacts from the influx of foreign workers in Indonesia.

Negative impact

1. Minimize employment opportunities for local workers.

The most pronounced negative impact of the influx of foreign workers is the of minimize employment opportunities in the country because the number of workers will increase. If it is not balanced with an increase in domestic business, employment opportunities will become decreasing.

2. Become a threat to local workers who do not have more skills.

The arrival of foreign workers in Indonesia become a threat for local workers, especially without skills at all. If not trained, local workers will not be able to compete with foreign workers.

3. Increasing unemployment for local workers.

The presence of foreign workers, if it is not balanced with additional employment opportunities, will only cause a lot of unemployment. As a solution, additional jobs must also be done.

That is why there needs policies and implementations of the empowerment of Indonesian workers in Chinese companies, so who are classified as unemployed become employed. Therefore, the government issued a policy through (Presidential Regulation No. 20/2018) concerning Foreign Workers and Indonesian Workers. In this regulation, an expert foreign worker is accompanied by 10 Indonesian workers. In this law, an expert Foreign Worker is accompanied by 10 Indonesian Workers, besides being absorbed in the field. They are also for transfer of knowledge and transfer of jobs, so the unemployedd people in this area can be reduced, and obtain jobs and positions in Chinese companies for local workers due to new provisions in the Presidential Decree which are not in accordance with Law No. 13 of 2003 concerning Manpower

The Presidential Regulation makes it easier for the process of bringing in foreign workers to work in Indonesia. This is considered to make it easier for foreign workers to enter Indonesia, and it will reduce the number of local workers. Thus, foreign workers fill more jobs in Indonesia. Consequenly it is necessary to conduct an analysis of the legal protection that can be carried out on local workers for using of foreign workers in the company, and what legal measures can be taken by local workers due to a violation of using of foreign workers in the companies. Talking about the problem of people who are still unemployed, we are talking about problems of public interest (Anindita, 2019).

Therefore, public policy is a solution to overcoming problems that occur in certain activities that occur in a community created by state institutions with the intention of carrying out bureaucratic activities (Wibawa, 2011). This definition, if it is related to the empowerment of workers who are still unemployed, then it is a solution through Presidential Regulation Number 20 of 2018 to help people who do not have permanent jobs, so they are not unemployed. Therefore, in relation to the empowerment of Indonesian Workers, public policy is placed as a theoretical reference in explaining this case. The right means the policy required the functioning of Chinese companies, so the government and Chinese companies need to help Indonesian Workers to be employed in existing Chinese companies. So, discussing the issue of public policy definitely refers to the government's program in investing in the form of the establishment of Chinese companies in this area and the program must be implemented in the area. Implementation can simply be interpreted as the implementation or application of a program so that implementation can be said to be a social action as well as an evaluation (Abubakar, 2012). The implementation of policies is an effort of the state or nonstate individually or in groups to achieve the goals in the policy. This implementation activity was only carried out after the policy was endorsed as well as legalization and the allocation of its resources had also been approved (Wibawa, 2011).

Thus, the policy implementation is a reciprocal relationship between the formulation of goals and the intended objectives so that goals can be achieved (Abubakar, 2012). To empower a workers are classified as powerless to become powerful, a program is needed that can make workers able and survive working in Chinese companies through the formulation of guidance and supervision, with education and training in foreign language skills, science and technology.

\section{Problems Formulation}

Referring to the background, several problems are formulated: (a) Are there policies and implementations to decrease the unemployment rate in Southeast Sulawesi Province? (b) How can an expert Chinese Foreign Worker be accompanied by 10 Indonesian Workers for transfering of knowledge and transfering of jobs? (c) How many Chinese workers and Indonesian Workers can work in Chinese companies?

\section{The Research Objectives}

The Research Objectives are: (a) To describe policies and implementations to decrease unemployment rates in Southeast Sulawesi Province; (b) To Analyze an expert Chinese Foreign Worker accompanied by 10 Indonesian Workers for transfer of knowledge and transfer of jobs; (c) To Identify Chinese Foreign Workers and Indonesian Workers who are employed in Chinese Companies.

\section{MATERIALS AND METHODS}

\section{The Research Design}

The research used a cross sectional design. The research location was in Konawe District, Southeast Sulawesi Province, and the research was conducted in July 2019. 


\section{Types of data and collection methods}

Primary data and secondary data research. Primary data were obtained from respondents, and secondary data were obtained from the Manpower Office of Konawe District, the Provincial Manpower Office, and the Immigration Office of Southeast Sulawesi Province. How to obtain data were: questionnaires, interviews, observation, and study documentation.

\section{The Population and sample}

Of the three Chinese companies that were deliberately sampled, 3 (three) Chinese companies with a total workforce of 9077 consisting of 958 Chinese workers and 8119 Indonesian workers. Determination of the number of samples used by researchers is based on the slovin method to calculate the minimum number of samples. if the behavior of the population is not known with certainty. The population is all workers in 3 (three) Chinese companies as shown in Table 1. For more details, the Slovin formula proposed by (Jalaluddin, 2002) is: From the population a sample is taken using the formula below.

$$
\begin{aligned}
& \text { n : Sample Size; } \\
& \text { (1) Where: } N \text { : Population; } \\
& \mathrm{d} \text { : Precision (0.1) } \\
& \mathrm{n}=\frac{\mathrm{N}}{\mathrm{N} \mathbf{d}^{2}+1}
\end{aligned}
$$

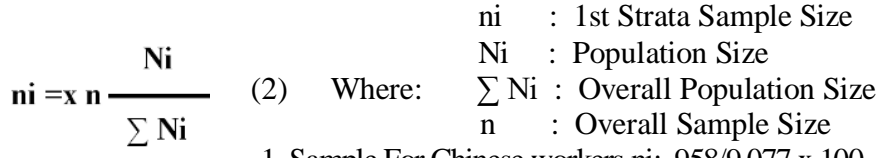

$$
\begin{aligned}
& \mathrm{n}=\frac{\mathrm{N}}{\mathrm{Nd}^{2}+1} \mathrm{n}=\frac{9.077}{9.077 \times 0,01+1} \\
& \mathrm{n}=\frac{9.077}{9.077(0,1)^{2}+1} \mathrm{n}=\frac{9.077}{91} \\
& \mathrm{n}=9974 \text { rounded to } 100
\end{aligned}
$$

2. Samples for Indonesian Workers ni: 8.119/9.077 x $100=90$ workers

The data source to determine the sample size was taken by the Chinese workers population of 958 people and the Indonesian

\begin{tabular}{|c|c|c|c|c|c|c|c|}
\hline \multirow{2}{*}{ No } & \multirow{2}{*}{ Companies } & \multicolumn{3}{|c|}{ Chinese Workers } & \multicolumn{3}{|c|}{ Indonesian Workers } \\
\hline & & Male & Female & Amount & Male & Female & Amount \\
\hline 1 & DSSP Power Company & 49 & - & 49 & 110 & - & 110 \\
\hline 2 & $\begin{array}{l}\text { Obsidian Stain less } \\
\text { Steel Company }\end{array}$ & 423 & 51 & 474 & 3531 & 125 & 3656 \\
\hline 3 & $\begin{array}{l}\text { Virtu Dragon Nikel } \\
\text { Industry Company }\end{array}$ & 409 & 26 & 435 & 4008 & 345 & 4353 \\
\hline & Total & 881 & 77 & 958 & 7649 & 470 & 8119 \\
\hline
\end{tabular}
workers population of 8119 people, so that the number is 9077 people. Based on the formula of Slovin, the sample size of 9077 sourced from three Chinese companies consisting of 958 Chinese workers and 8.119 Indonesian workers. Based on this measure, it can be calculated in the following Table 1. Formulas for Samples in Each Section, sourced from 958 Chinese workers and 8119 Indonesian workers. Based on this measure, so the sample size of each section can be seen in the following Table 2.

Table 1. The Workers Population Data Collection in Konawe Regency in 2019 (Source: Primary Data)
Table 2. List of Total Workers at three Chinese Companies (Source: Primary Data)

\begin{tabular}{|c|c|c|c|}
\hline No & Workers Sample & $\begin{array}{c}\text { Total Population } \\
\text { (people) }\end{array}$ & $\begin{array}{c}\text { Number of } \\
\text { Samples (people) }\end{array}$ \\
\hline I. & $\begin{array}{c}\text { Sample of Chinese } \\
\text { Workers }\end{array}$ & 958 & 10 \\
\hline 2. & $\begin{array}{c}\text { Sample of } \\
\text { Indonesian } \\
\text { Workers }\end{array}$ & 8119 & 90 \\
\hline & Total & $\mathbf{9 0 7 7}$ & $\mathbf{1 0 0}$ \\
\hline
\end{tabular}

\section{DATA ANALYSIS}

Data analysis in the research are a flow model analysis, correlational analysis, and Workers perception analysis.

\section{Design of Flow Model Components of Data Analysis}

Descriptive-qualitative analysis uses content analysis through data reduction, data display, and concurrent drawing / verification (Huberman and Miles, 1992). Data reduction is defined as the process of selecting, focusing attention on simplifying, abstracting, and transforming the raw data that emerge from field notes, then which dimensions and indicators are discarded and used, which are summarized in such a way that conclusions can be drawn. Presentation of the data used in the form of narrative text in the research, which is supported by presentations in the form of tables and pictures.

$$
\mathrm{r}_{\mathrm{xy}}=\frac{\mathrm{n} \sum \mathrm{x}_{\mathrm{i}} \mathrm{y}_{\mathrm{i}}-\left(\sum \mathrm{x}_{\mathrm{i}}\right)\left(\sum \mathrm{y}_{\mathrm{i}}\right)}{\sqrt{\left.\mathrm{n} \sum \mathrm{x}_{\mathrm{i}}^{2}-\left(\sum \mathrm{x}_{\mathrm{i}}\right)^{2}\right\}\left\{\mathrm{n} \sum \mathrm{y}_{\mathrm{i}}{ }^{2}-\left(\sum \mathrm{y}_{\mathrm{i}}\right)^{2}\right\}}}
$$

The Largest score - The smallest score

$$
\text { Total score }
$$

$$
5-1 / 5=4 / 5=0.8
$$

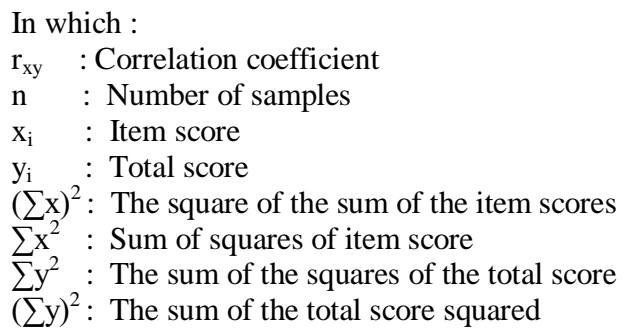

\section{Correlation Analysis Design}

Correlation analysis can be defined as a relationship, which aims to see the pattern and closeness of the relationship between two or more variables. The direction of the relationship between two variables can be divided into (1) Direct correlation is the change in the dependent variable with the independent variable significantly with the same direction of movement, (2) Negative 
correlation, namely changes in the dependent variable with the independent variable with the opposite direction of movement, (3) Zero Correlation, namely the direction of the irregular dependent variable relationship and independent (Pratisto, 2004). Based on the above, the Product Moment correlation technique can be used in the research with the formula (Sugiyono, 2010).

\section{Workers Perception Analysis}

Design Concerning questions about the views of workers on existing companies using a Likert scale with intervals of 15. Regarding the view of the workers on policy and implementation, assistance and opportunities to obtain the labor market, the questions with the answer are very good with a score of 5 and very bad with a value of 1 .

Because of the assessment criteria for the questionnaire on the three elements of the above questions, from the Likert Scale formula (Mueller, 1992), it can calculate the answer rank. According to the formulation described above, a table can be made to assess the respondents' answers which are included in the questionnaire that has been designed so that the level of accuracy of the answers of the respondents can be known. The assessment criteria are as described in Table 3.

Table 3. Ratings for the Questionnaire (Source: Primary Data)

\begin{tabular}{|l|l|c|}
\hline Score & Assessment criteria & Information \\
\hline $4.3-5$ & Very good & A \\
\hline $3.5-4.2$ & Good & B \\
\hline $2.7-3.4$ & Neutral & C \\
\hline $1.9-2.6$ & Bad & D \\
\hline $1-1.8$ & Worst & E \\
\hline
\end{tabular}

\author{
Where: \\ $\mathrm{M}=$ Acquisition of interpretive figures \\ (Media / Numbers) \\ $\mathrm{f}=$ Answer frequency \\ $\mathrm{x}=$ Weighting \\ $\sum=$ Sums \\ $\mathrm{n}=$ Number of respondents
}

\section{RESULTS AND DISCUSSION}

\section{Unemployment Policies and Implementations in Southeast Sulawesi Province}

To reduce the unemployment rate in Southeast Sulawesi Province as low as possible, a policy was issued through products (Aly, 2003) regarding the use of foreign workers with the hope that: (1) providing jobs to foreign workers must have a formal permit from the minister or an appointed official, (2) foreign workers who work in Indonesia only for a certain period, (3) foreign workers who working period has expired cannot be extended and can be replaced by other foreign workers.

The implementation was then clarified through (Presidential Regulation No. 20 of 2018). In this Regulation it is said that the use of Foreign Workers is carried out by those who provide jobs in relation to work for a certain position and for a certain time by looking at the condition of the labor market in Indonesia. According to this regulation, the utilization of Indonesian workers must be prioritized in all types of existing positions. In the event that the position cannot be occupied, the position can be filled by outside personnel, then this employee is not allowed to hold a position that handles employment issues or other positions determined by the Ministry of Manpower in applicable regulations. This regulation also states that Foreign Workers in certain fields can provide jobs to those concerned who are currently given a job from the one who gave the job in the same position, until their work contracts are end. It is stated in the regulation that companies who provide jobs using foreign workers must have a plan for using foreign workers that is approved by the appointed Minister and contains at least (1) logical arguments for using foreign workers, (2) the position of foreign workers in the company structure, (3) how long does it take to use foreign workers, and (4) choose Indonesian workers to accompany foreign workers.

Providers who using Foreign Workers without having a Plan of using Foreign Workers such personnel who are (1) who have shares occupying members of the Board of Directors of those who provide Foreign Workers, (2) foreign diplomatic employees, or (3) Foreign Workers that their works are required by the government. For sudden activities, the providers of the Foreign Workers can employ the Foreign workers by submitting an application to legalize the Plan for Employing Foreign Workers to the authorized official a maximum of two working days after Foreign workers are employed. Furthermore, to legalize the Plan for Using Foreign Workers is a maximum of 1 (one) day of activity, and it will be given after the application is fully responded. It is affirmed in this regulation that the providers of the foreign workers who will employ them submitting data of the foreign workers which includes: (1) the identity of the foreign workers, (2) nationality, (3) ownership of the passport and the place where the passport is issued, (3) position and period of time, (4) a statement of guarantee and the providers of the Foreign Workers, and (5) diplomas certificate and work experience, the competencies possessed are identical to the position they will occupy. The official will notify the notification of data acceptance of prospective Foreign Workers within two working days and a copy is submitted to the Directorate General of Immigration. According to this regulation, the providers of foreign workers must pay compensation for using of foreign workers after receiving a notification and it is made at a bank trusted by the Minister which is non-tax state revenue. The realization of the formulations contained in the presidential laws and regulations then established several Chinese companies engaged in the industrial sector to employ Indonesian workers and Chinese workers, so the government's aspiration to reduce unemployment could be achieved.

The role of the industrial sector in economic development in Indonesia is very important because it has advantages in accelerating development. The industrial sector can play a key role as an engine of development because it has superior value compared to other sectors because the value of capital capitalization is very large, the ability to absorb large workers, the ability to create value added from each input or basic material processed (Muhtamil, 2017). Furthermore, industry also has a role as the leading sector. With the presence of industrial development, it will spur and lift the development of other sectors. For example, the rapid growth of the industrial sector will stimulate the growth of the agricultural sector to provide materials for an industry. These industries also allow the development of the service sector, for example the establishment of a financial institution, marketing agency, or advertising, all of which support the growth rate of the industry (Arsyad, 2010). However the industrial sector in Indonesia is relatively high, it is not or has not been able to be followed by the 
development or growth of employment. Further policies are needed so that many industries that are developing in Indonesia are labor intensive, so that the absorption of their workers can also increase, considering that the industrial sector is one of the main pillars of the Indonesian economy (Zilfiyah, 2013).

Broudel (1982) divides four forms of industrial activity, the first form, which is usually headed by an employer and employs two or three traveling traders and one or two apprentices. The division of workers is simple and there is even no division of workers at all. The second form, the trading business is everywhere, but still in contact with one another. A businessman acts as a kind of director or coordinator. The entrepreneur provides the individual businesses with raw materials, ensures that work is done, pays workers salary, and markets the final product. The third form, is the concentrated factory, which is different from the first and second forms. The workers no longer work in their homes but come to the factory to complete a series of tasks under one roof. A division of labor already exists, resulting in increased productivity by manual. The fourth form, is manufacturing, the level of technology used is the machine (Sanderson, 1993)

\section{Expert Assistance Analysis for Foreign Workers}

The Assistance is an expert Chinese Foreign Worker accompanied by 10 Indonesian Workers, for transferring of knowledge and jobs, so Indonesian Workers can work in the Chinese company on the other hand Chinese Foreign Workers can also work with Indonesian Workers. For example, training in English and Indonesian language, so they can make social interactions both in work days and out. The approach needed to use is the "learning process" approach which has three dimensions. They are the structural dimension, the cognitive dimension and the participatory dimension (Korten and Norman, 1981). The explanation of the three dimensions are:

\section{a. Structural Dimension}

The structural dimension discusses the design of the supervisory structure from the central to the regencies and cities and is structurally as follows: -The central prepares a guidance / supervision model -Province coordinates with the central and regencies / cities in terms of guidance / control of the company-District / City conduct direct guidance / supervision to the companies in districts / cities.

\section{b. The Cognitive Dimension}

The cognitive dimension discusses: (1) The implementation of education and training for foreign language skills, both English and Indonesian, (2) Link-and-matched programs with missionary demands of the production world are carried out / business in projects that are crash programs oriented to training / guidance to workers, so they are ready to work.Talking about cognitive problems, assitance is very important in this company. The important matters discussed in assitance are discussed in the Table 4. According to the Table 4 an instructor in training concerning theory and practice must have the following basic principles: (a) A facilitator and an instructor must have an idea about what knowledge will be provided to the workers. After the ideas possessed by the facilitator and instructor, then the ideas will be narrated to the workers either in the room or in the field. After narrative is carried out, the following stage is an action that the workers can carry out experiments with the guidance of a facilitator or instructor, and it is hoped that the workers can work in their respective fields according to the knowledge they have acquired. Thus, the construction of the material includes: (1) material classification includes quantitative and qualitative material, (2) the order of the material in the systematic sense of the material to be presented, so participants are not confused about receiving the material, (3) describing the theory and then training to try the material received when they enter the actual work they already believe in themselves about the material, (4) a description and syllabus of the material needs to be given as a guide for practicing, (5) the weight of the material, in the sense of how many contents of the material and how many hours the material was given.

Table 4. Development Assistance

\begin{tabular}{|c|c|c|}
\hline No & Assistance Dimension & Assistance Indicator \\
\hline 1 & Assistance Concept & $\begin{array}{c}\text { Assistance Concept is a reciprocal } \\
\text { relationship between foreign workers } \\
\text { and Indonesian workers who cannot } \\
\text { speak foreign languages. }\end{array}$ \\
\hline 2 & Assistance Purpose & $\begin{array}{c}\text { Increase the capacity of the workers in } \\
\text { operating the foreign company program }\end{array}$ \\
\hline 3 & Assistance Strategy & $\begin{array}{c}\text { Intensifying efforts to empower workers } \\
\text { to increase their personal capacity }\end{array}$ \\
\hline 4 & Assistance Tasks & $\begin{array}{c}\text { Conducting focused discussions and } \\
\text { implementing training and Assistance }\end{array}$ \\
\hline
\end{tabular}

Table 5. Methods and Techniques of Manpower Learning (Source: Primary Data)

\begin{tabular}{|c|c|c|}
\hline No & Methods & Techniques \\
\hline 1 & Discussion & Question and answer \\
\hline 2 & Group Work & group discussion \\
\hline 3 & Discovery & Reading and Discussion \\
\hline 4 & Brainstorming & Demonstration \\
\hline 5 & Inquiry or research & Syimposium \\
\hline 6 & Experiment & Panel \\
\hline 7 & Field Trips & Panel discussion \\
\hline 8 & Field Work & Seminar \\
\hline 9 & Role Playing & Colloquy \\
\hline 10 & Case Study & Lecture \\
\hline 11 & Dialogue & Cooperative Learning \\
\hline 12 & Problem solving & Quiz questions, and others \\
\hline
\end{tabular}

After the contents of the material are given, the training methodology is practiced, which includes: (1) the approach used, are in the form of lectures, taking notes or discussing the material, (2) what learning methods or techniques are used, (3) what media are used for learning, whether using a blackboard, powerpoints or other media, (4) which institutions are the organizer, (5) who are the instructors and the facilitators. In order for participants to understand both theoretically and practically, instructors need to apply learning methods and techniques as in the table below. The explanation above illustrates the importance of transfering of knowledge and transfering of jobs, both regarding science and technology material as well as material on foreign languages, both English and Indonesian. To get the best solution so that it does not harm both Chinese 
workers and Indonesian workers, a focus group discussion was formulated for the implementation of unemployment, assistance for foreign workers who were experts, development of mentoring, methods and techniques for learning workers in Konawe Regency, Southeast Sulawesi Province. (FGD) at the provincial level attended by officials from related institutions such as the Provincial, Regency and City Manpower Office, Department of Immigration, Department of Education, Department of Tourism, Department of Environment, Higher Education and others, who are expected to get the best way so as not to cause conflict hidden or potential or open conflicts between Chinese workers and Indonesian workers. The results showed that 64 respondents said it was very important, while 4 respondents said it was not important. This is clearly described in the table below. Based on Table 6, the respondent's answer to the statement about the importance of Science and Technology in the work obtained an interpretation figure of 4.3, so based on the assessment criteria it is in the "very important" category.

\section{c. Participatory Dimension}

The participatory dimension is oriented towards an approach that is more involved in the nature of local government in both guidance and supervision. In addition, this approach allows local governments and companies to conduct evaluations in determining objectives and formulating policies for the operation of these companies.

\section{Identification of workers Absorption}

After identifying the population in the three Chinese companies, it turns out that the ratio of workers who work in the three Chinese companies shows that as many as 8,119 Indonesian workers work in three Chinese companies and as many as 958 Chinese workers who also work in the three Chinese companies. To complete the data presented in table form, a visual graphic is shown so that it is easy to read and to understand by readers about the high and low absorption of Chinese workers and Indonesian workers in the three Chinese companies in Konawe Regency, Southeast Sulawesi. Based on table 7 . It can be said that not all workers can speak foreign languages, but some can speak foreign languages.

Table 6. Respondents' Answers about the Importance of Science and Technology (Source: Primary Data)

\begin{tabular}{|l|l|c|c|c|c|c|}
\hline No. & \multicolumn{1}{|c|}{$\begin{array}{c}\text { alternative } \\
\text { answers }\end{array}$} & & $\mathbf{f}$ & $\mathbf{( x )}$ & $\mathbf{f}(\mathbf{x})$ & $M=\frac{\sum f(x)}{n}$ \\
\hline 1. & Very important & & 64 & 5 & 320 & $429 / 100$ \\
2. & important & 5 & 4 & 20 & \\
3. & Quite important & 27 & 3 & 81 & \\
4. & Not important & 4 & 2 & 8 & \\
5. & Very unimportant & & 0 & 1 & 0 & \\
\hline & Total & & $\mathbf{1 0 0}$ & & $\mathbf{2 9}$ & $\mathbf{4 . 3}$ \\
\hline
\end{tabular}

Table 7. Results of Workers Absorption in 2019

\begin{tabular}{|c|l|c|c|c|c|c|c|}
\hline No & \multicolumn{2}{|c|}{ Companies } & \multicolumn{3}{|c|}{ foreign workers } & \multicolumn{3}{c|}{ Indonesian workers } \\
\cline { 2 - 8 } & Male & Female & Amount & Male & Female & Amount \\
\hline 1 & $\begin{array}{l}\text { DSSP Power } \\
\text { Company }\end{array}$ & 49 & - & 49 & 110 & - & 110 \\
\hline 2 & $\begin{array}{l}\text { Obsidian Stain less } \\
\text { Steel Company }\end{array}$ & 423 & 51 & 474 & 3531 & 125 & 3656 \\
\hline 3 & $\begin{array}{l}\text { Virtu Dragon Nikel } \\
\text { Industri Company }\end{array}$ & 409 & 26 & 435 & 4008 & 345 & 4353 \\
\hline \multicolumn{2}{|c|}{ Total } & 881 & 77 & 958 & 7649 & 470 & 8.119 \\
\hline
\end{tabular}

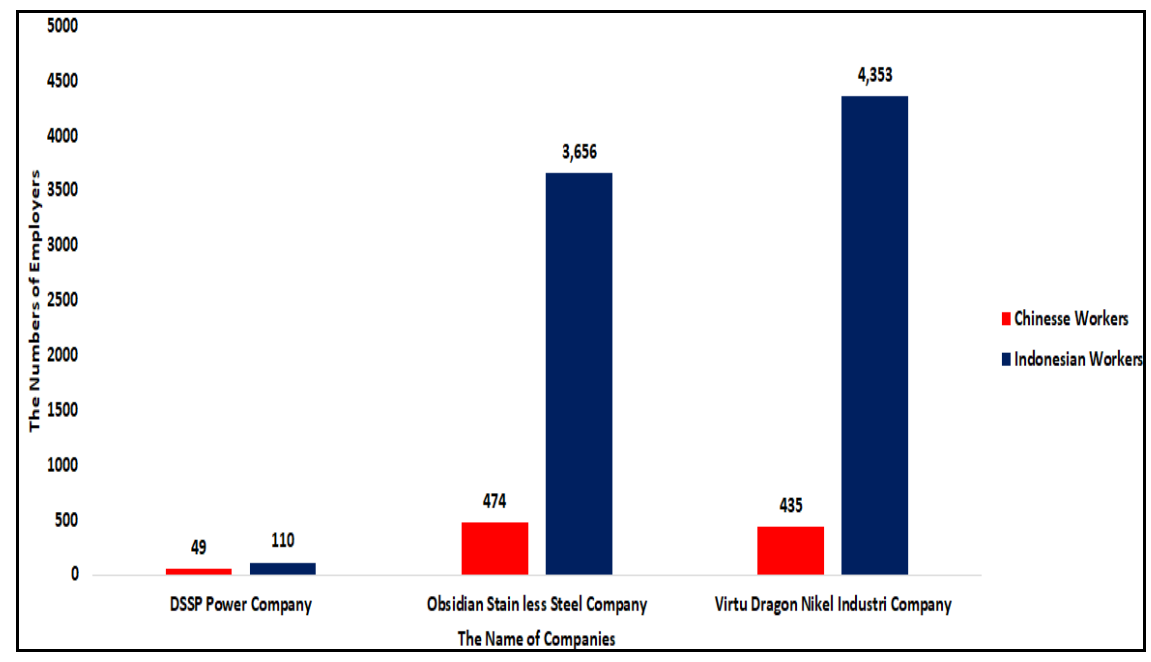

Figure 1. Results of Workers Absorption in 2019
Indeed, there are certain parts that require foreign language skills, but there are certain parts that do not need to be proficient in foreign languages, such as cleaning services, company security, cooks, and others.It was tried to be identified through research samples in general that we could find out how many could speak a foreign language and how many could not. The results showed that foreign workers fluent in foreign languages were 4 respondents (4\%), and who could not speak foreign languages were 5 respondents $(5 \%)$. Meanwhile, as many as 27 indonesian workers could speak foreign languages $(27 \%)$, and who were not fluent in foreign languages 64 respondents $(64 \%)$. The real thing can be seen in the table 8 .
Table 8. Distribution of Examples based on Foreign Language Mastery

\begin{tabular}{|c|c|c|c|c|c|c|c|c|c|}
\hline \multirow{3}{*}{$\mathrm{No}$} & \multirow{3}{*}{ Companies } & \multicolumn{4}{|c|}{ foreign workers } & \multicolumn{4}{|c|}{ Indonesian workers } \\
\hline & & \multicolumn{2}{|c|}{ Yes } & \multicolumn{2}{|c|}{ No } & \multicolumn{2}{|c|}{ Yes } & \multicolumn{2}{|c|}{ No } \\
\hline & & $\mathrm{n}$ & $\%$ & $\mathrm{n}$ & $\%$ & $\mathrm{n}$ & $\%$ & $\mathrm{n}$ & $\%$ \\
\hline 1 & DSSP Power Company & 0 & 0 & 5 & 5 & 7 & 7 & 0 & 0 \\
\hline 2 & Obsidian Stainless Steel Company & 2 & 2 & 0 & 0 & 10 & 10 & 31 & 31 \\
\hline 3 & Virtu Dragon Nikel Industri Compa & 2 & 2 & 0 & 0 & 10 & 10 & 31 & 31 \\
\hline & Total & 4 & 4 & 5 & 5 & 27 & 7 & 64 & 64 \\
\hline
\end{tabular}

Table 9. Sample Distribution Based on the Payroll System (Source: Primary Data)

\begin{tabular}{|c|c|c|c|}
\hline \multirow[b]{2}{*}{ No } & \multirow[b]{2}{*}{ Companies } & \multicolumn{2}{|c|}{ Salary (Rp) / Month } \\
\hline & & $\begin{array}{l}\text { Chinese } \\
\text { Workers }\end{array}$ & $\begin{array}{l}\text { Indonesian } \\
\text { Workers }\end{array}$ \\
\hline 1 & $\begin{array}{c}\text { DSSP Power } \\
\text { Company }\end{array}$ & $\begin{array}{c}\text { ten } \\
\text { million }\end{array}$ & $\begin{array}{l}\text { two million five } \\
\text { hundred thousand }\end{array}$ \\
\hline 2 & $\begin{array}{c}\text { Obsidian Stainless } \\
\text { Steel Company }\end{array}$ & $\begin{array}{c}\text { ten } \\
\text { million }\end{array}$ & $\begin{array}{l}\text { two million five } \\
\text { hundred thousand }\end{array}$ \\
\hline 3 & $\begin{array}{l}\text { Virtu Dragon Nikel } \\
\text { Industri Company }\end{array}$ & $\begin{array}{c}\text { ten } \\
\text { million }\end{array}$ & $\begin{array}{l}\text { two million five } \\
\text { hundred thousand }\end{array}$ \\
\hline
\end{tabular}


Workers who master Science and Technology, foreign languages, and others that Chinese companies provide different salaries for Chinese workers and Indonesian workers. In addition, in Chinese companies there has been discrimination between Chinese workers and Indonesian workers. It means that modernization or development is understood as something that eliminates all the realities of a bad situation. The ideology advocates idealistic and pragmatic development is a development trait that emphasizes economic growth, and is based on market mechanisms. The benefits obtained are assumed to extend to all sectors in society. This proposition is known as the "trickle-down effect". The welfare of society in general will be obtained through economic growth with the market as the guide. However, this theory is no longer relevant in alleviating poverty in Chinese companies, which was originally expected to help in general reduce the poverty rate in Indonesia by 7,05 million in 2019 (Central Bureau of Statistics, 2019) was not reach. The high unemployment rate that has been stated, there have been various criticisms of the empowerment model that has been implemented, such as overcoming unemployment which is applied in developing countries, especially in Indonesia by using the "trickle down effect" argument that is considered to have failed. According to this approach, what is very important is economic growth due to investment (the wealthy). The consequence is that the underprivileged will be affected or a drop from economic growth caused by economic productivity of the rich. However, in reality this is not hanppened. In addition, this approach has a mode of production that is profit-oriented as much as possible and places workers as tools of production who must follow the wishes of the company owner. Development should prioritize economic growth, with the hope that in time that growth will trickle-down effect and improve people's welfare by itself. If the income in table 9 is measured using the Central Bureau of Statistics indicator, the income level for one family is included in the poor category. If the total income is divided by at least 4 family members, the family is not prosperous or poor, because Cen tral Bureau of Statistics determines that an income of Rp 1.9 million per month is categorized as a poor family (Iskandar, 2019).

When compared to Abubakar research (2012) about the poor family. According to (Central Bureau of Statistics, 2017) explained that the Poverty Line is the sum of the Food Poverty Line and the Non-Food Poverty Line. People who have an average expenditure per capita per month below the poverty line are categorized as poor. Food Poverty Line is the minimum food expenditure, which is equivalent to 2100 kilocalories per capita per day.

Table 10. Distribution of Examples by

Education Level (Source: Primary Data)

\begin{tabular}{|l|c|c|c|c|c|c|}
\hline \multirow{2}{*}{$\begin{array}{c}\text { Level of } \\
\text { Education }\end{array}$} & \multicolumn{2}{|c|}{$\begin{array}{c}\text { Chinesse } \\
\text { Workers }\end{array}$} & \multicolumn{2}{c|}{$\begin{array}{c}\text { Indonesian } \\
\text { Workers }\end{array}$} & \multicolumn{2}{c|}{ Total } \\
\cline { 2 - 7 } & $\mathrm{n}$ & $\%$ & $\mathrm{n}$ & $\%$ & $\mathrm{n}$ & $\%$ \\
\hline $\begin{array}{l}\text { Primary } \\
\text { school }\end{array}$ & 0 & 0 & 0 & 0 & 0 & 0 \\
\hline $\begin{array}{l}\text { Junior High } \\
\text { School }\end{array}$ & 0 & 0 & 0 & 0 & 0 & 0 \\
\hline $\begin{array}{l}\text { Senior High } \\
\text { School }\end{array}$ & 0 & 0 & 30 & 30 & 30 & 30 \\
\hline Diploma & 2 & 2 & 4 & 4 & 6 & 6 \\
\hline Bachelor & 5 & 5 & 32 & 32 & 37 & 37 \\
\hline Magister & 2 & 2 & 25 & 25 & 27 & 27 \\
\hline Doctor & 0 & 0 & 0 & 0 & 0 & 0 \\
\hline Total & 9 & 9 & 91 & 100 & 100 & 100 \\
\hline
\end{tabular}

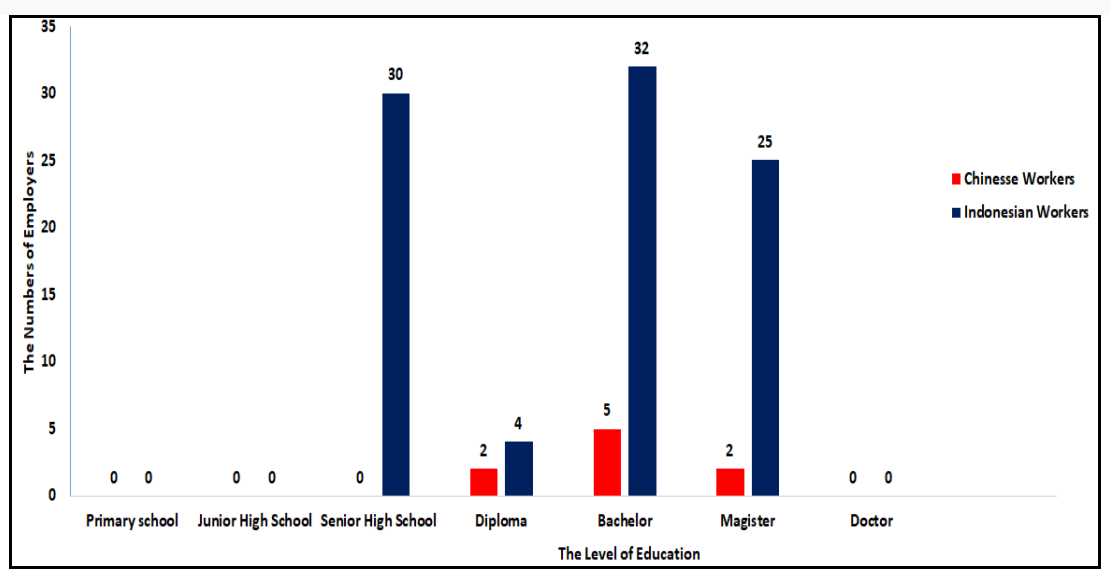

Figure 2. Distribution of Examples by Education Level (Source: Primary Data)

Commodity packages for basic food needs are represented by 52 types of commodities (grains, tubers, fish, meat, eggs and milk, vegetables, nuts, fruits, oils and fats, etc.). The Non-Food Poverty Line is the minimum need for housing, clothing, education and health. Commodity packages for non-food basic necessities are represented by 51 types of urban commodities and 47 types of commodities in rural areas. So according to (Abubakar, 2012). It can be confused the local government when there are funds from the central government. The central government uses the poverty rate generated by Central Bureau of Statistics, while the local government uses the National Family Planning Coordinating Board criteria as the target. It is uniformity also causeed conflict at the local community level. To complete the data presented in table form, a visual graphic is shown so that it is easy to read and to understand by readers about the high and low absorption of Chinese workers and Indonesian workers in the three Chinese companies in Konawe Regency, Southeast Sulawesi

Even though it is seen from the level of education between Foreign Workers (Chinese Workers) and Indonesian Workers who both have the same level of education, for example they are both undergraduate, but the treatment is different. Indonesian workers in the company are placed as waiters for eating and drinking and cleaning the room, office yard etc., while the Chinese workers are placed in structural positions in the company. Discrimination between Chinese workers and Indonesian workers if examined through: Interest Theory. The theory of interest considers Chinese workers who work in Indonesia to be rational if there is no discrimination. This can be seen from the basic assumptions: First, Chinese companies always try to do something to fulfill the interests of their companies. Second, focus attention on actors and question whether the actions taken are based on certain reasons that are considered good (Ian, 1994). In this theory, Chinese companies are considered behaving to fulfill their interests. When the theory of interest is used to understand Chinese companies, company owners assume that all forms of action that come from these companies are profitable. Due to the interest of gaining profit, according to Marx and Engels, they developed "Dialectical Materialism" as an approach to Chinese Workers and Indonesian Workers. Marx and Engels divided society into Modes of Production, and Infrastructure. Mode of Production is divided into two; the power of production and the production relationship. Production power consists of raw materials and the production relationship refers to ownership of 
production. In the infrastructure component, Marx divides two types of relations; the type of superordinate and the type of subordinate (Sanderson, 1993). It is possible that the power of Chinese Workers as superordinate and Indonesian Workers as subordinate, so that the treatment is also different between Chinese workers and Indonesian workers in these three companies, there are different treatments when compared to the Japanese company (Yanagi Histalaraya company) in Kendari City and DSSP Power company, Obsidian Stainless Steel company, and The Virtu Dragon Nickel Industry company that owned by China in Konawe District which had a comparative study conducted to compare the treatment between the two countries in their respective companies. Treatment socially, culturally and religion as described in the Table 11.

Table 11. Differentiation of Treatment of Chinese company and Non-Chinese Company

\begin{tabular}{|c|l|l|}
\hline No & \multicolumn{1}{|c|}{ Japanese Company } & \multicolumn{1}{|c|}{ Chinese Company } \\
\hline 1 & $\begin{array}{l}\text { Indonesian workers are not obliged to be taught the language of the } \\
\text { country of the owner }\end{array}$ & Indonesian workers must be taught Chinese \\
\hline 2 & Expert Indonesian workers have positions according to their expertise & Indonesian workers are experts as servants of consumption \\
\hline 3 & Indonesian workers have overtime pay & Indonesian workers do not have overtime pay \\
\hline 4 & Indonesian workers have CSR & Indonesian workers do not have CSR \\
\hline 5 & The working hours of Indonesian workers are not more than 40 hours/week & The working hours of Indonesian workers are more than 40 hours / week \\
\hline 6 & Allowing prayers etc. & Do not allow worship / prayer \\
\hline 7 & $\begin{array}{l}\text { The Chinesse workers are recruited from good people, not } \\
\text { Criminals and ex- Soldiers }\end{array}$ & The Chinese worker are recruited from convicts and ex-Soldiers \\
\hline 8 & Indonesian workers are paid a fair amount according to their expertise & Indonesian workers are not properly paid as they wish \\
\hline 9 & The company does not destroy nature & Chinese companies destroy the natural environment \\
\hline 10 & Chinese workers are not ex-soldiers & Many Chinese workers are ex-soldiers \\
\hline
\end{tabular}

The production power is held by superordinate and forces subordinate to follow its will, then creates co-conflict, so it needs to be approached through the 'Conflict Theory' It is impressed by us that when the demonstration about the discrimination of Chinese workers shows that the Conflict Theory raises the contradiction between the entry of Chinese workers and Indonesian workers, when viewed from Law Number 13 of 2003 (Ian, 1994). The contradiction between the two workers could be wrong because if the theoretical approach is raised to a more paradigmatic level, the two groups of workers actually come from one paradigm.

Table 12. Basic Assumptions of Conflict Theory

\begin{tabular}{|c|l|}
\hline No & \multicolumn{1}{|c|}{ Basic Assumptions } \\
\hline 1 & Interests are a basic element of social life \\
\hline 2 & Social life involves encouragement \\
\hline 3 & Society needs to be divided \\
\hline 4 & Social life gives rise to opposition \\
\hline 5 & Social life gives rise to structural conflicts \\
\hline 6 & The social system gives rise to the parts of the interests \\
\hline 7 & Social differentiation will involve power \\
\hline 8 & $\begin{array}{l}\text { Social systems are not integrated and are overwritten by } \\
\text { contradictions }\end{array}$ \\
\hline 9 & Social systems tend to change \\
\hline
\end{tabular}

Correlations

\begin{tabular}{|c|c|c|c|c|}
\hline \multirow{2}{*}{ variable } & & $\begin{array}{c}\text { mastery } \\
\text { of skills }\end{array}$ & $\begin{array}{c}\text { mastery of foreign } \\
\text { languages }\end{array}$ & $\begin{array}{c}\text { accepted as an } \\
\text { employee }\end{array}$ \\
\hline \multirow{2}{*}{$\begin{array}{c}\text { mastery } \\
\text { of skills }\end{array}$} & Pearson Correlation & 1 & $.822^{* *}$ & $.822^{* *}$ \\
\cline { 2 - 5 } & Sig. (2-tailed) & & .000 & .000 \\
\cline { 2 - 5 } & $\mathrm{N}$ & 100 & 100 & 100 \\
\hline $\begin{array}{c}\text { mastery } \\
\text { of foreign } \\
\text { languages }\end{array}$ & Pearson Correlation & $.822^{* *}$ & 1 & $1.000^{* * *}$ \\
\cline { 2 - 5 } & Sig. (2-tailed) & .000 & & .000 \\
\hline \multirow{2}{*}{\begin{tabular}{c} 
accepted $\begin{array}{c}\text { as an } \\
\text { employee }\end{array}$ \\
\cline { 2 - 5 }
\end{tabular}} & Pearson Correlation & $.822^{* * *}$ & 100 & 100 \\
\cline { 2 - 5 } & Sig. (2-tailed) & .000 & .000 & 1 \\
\hline \multirow{2}{*}{} & $\mathrm{N}$ & 100 & 100 & 100 \\
\hline
\end{tabular}

It is the social fact paradigm. The reason the researchers included the two groups of workers in one paradigm was because they both essentially questioned the structure of the economy. This means that from the economic aspect there is discrimination of skill workers and unskilled workers, which is seen in the payroll system and the division of positions in the company structure between Chinese Workers and Indonesian Workers. This can be seen from the basic assumptions in the Table 12.The contradiction between the two workers could be wrong because if the theoretical approach is raised to a more paradigmatic level, the two groups of workers actually come from one paradigm. It is the social fact paradigm. The reason the researchers included the two groups of workers in one paradigm was because they both essentially questioned the structure of the economy. This means that from the economic aspect there is discrimination of skill workers and unskilled workers, which is seen in the payroll system and the division of positions in the company structure between Chinese Workers and Indonesian Workers. When compared to research Abubakar (2020) about the company payroll system in Batam, Riau Islands Province. Payroll System for Foreign Workers and Indonesian Workers Generally the amount of salary earned by employees at PT.Kemet, it is openly, employees who have jobs or have skill workers are given a standard salary that is appropriate to at least follow the Regional Minimum Salary. The reason why PT.Kemet gives salary based on Regional Minimum Salary. They are : (1) if the worker has a family, he must bear a heavy burden of life so that he is given an adequate salary to be able to support his family and other consumption, so they can continue to work in the company; (2) to avoid the occurrence of a negative assessment of the company, do not judge that the company is only looking for profit as much as possible, while workers' salaries are not considered, in other words do not let the company be considered to place workers as mere means of production but must be respected the right to leave, relax and more.

\section{Factors Influencing Workers Absorption in Chinese Companies}

The correlation coefficient value is 0.822 , which means that the relationship between mastery of skills, both mastery of ICTs, IT, machines and others and acceptance as employees is very close. The correlation coefficient marked (+) means the relationship between ICTs, IT, machines and others is unidirectional, so if ICTs, IT, machines and others are well controlled, they will be accepted as employees in the Chinese company. The correlation coefficient of 1,000 means that the relationship 
between mastery of a foreign language and acceptance as an employee is very close. The correlation coefficient marked $(+)$ means that the relationship between mastery of a foreign language and acceptance as an employee is unidirectional, so if the foreign language is mastered properly, it will be accepted as an employee at the Chinese company. The correlation coefficient is 0.822 , which means that the relationship between mastery of skills, both mastery of ICTs, IT, machines and others with mastery of foreign languages is very close. The correlation coefficient marked (+) means the relationship between skill mastery and foreign language mastery is unidirectional so that if the foreign language is mastered well it is easy to master ICTs, IT, machines and others because all the terms ICTs, IT, machines and others are written in foreign language in the Chinese company.

\section{CONCLUSION}

The conclusions of the research are: (a) The policy that is taken to organize the workers is the issuance Laws and regulations on Manpower. (b) To improve the quality of Foreign Workers and Indonesian Workers, assistance is provided to train science and technology as well as foreign languages so that workers are able to work in Chinese companies as a result of the transfer of knowledge and transfer of jobs from experts and it is hoped that the Chinese experts can be accompanied by 10 Indonesian Workers. (c) From the identification results in the Chinese companies, it is known that 9 workers work in Chinese companies, while 91 Indonesian workers are also absorbed in Chinese companies, although there is discrimination in terms of pay, where Chinese Foreign Workers are greater than Indonesian workers

\section{Acknowledgement}

The research can run well and perfectly, because it is financed by the Central Government, in this case, from the Ministry of Higher Education Technology Research in accordance with the work contract No. 2906 / I.4 / PP / 2019. Therefore, on this valuable opportunity we would like to express our utmost respect and appreciation for the research fund

\section{REFERENCES}

Aly, B. (2003). Undang-Undang Ketenagakerjaan Republik Indonesia No.13. [Manpower Act of the Republic of Indonesia Number 13]. Jakarta, PT.Serambi Semesta Distribusi.

Arsyad, L. (2010). Economic development [Ekonom Pembangunan]. Yogyakarta, UPP STIM YKPM,Yogyakarta.

Abubakar, I. (2019). Food Expenditure Criteria Analysis, Statistics Center, World Bank and Sayogyo Professor to Determine Benchmarking. International Journal of Civil Engineering and Technology, 10 (05), 943-953. http://www.iaeme.com/IJCIET/index.asp

Anindita,,S.N. (2019). Protection of local labor laws for the entry of foreign workers after the entry into force of presidential regulation number 20 of 2018. Jurist-Diction, 2 (3), 1127-1145. https://doi.org/10.20473/jd.v3i3.18622

Broudel, F. (1982). The Wheels of Commerce. Civilization and Capitalism, 15 th-18 th Century, 298-344, New York: Harper \& Row.

Huberman, M., \& Miles, M.B. (1992). Qualitative Data Analysis [Analisa Data Kualtatif]. Transleted to Indonesian Language by Tjetjep Rohandi Rohidi from the original book Qualitative Data Analysis. 37-58, Jakarta. Universitas Indonesia.

Iskandar, A. (2012). Policy and Implementation of Community Empowerment through Salt Factory [Kebjakan dan Implementasi Pemberdayaan Masyarakat Melalui Pabrik Garam]. Jurnal Sosial Humaniora, 3 (1), 9-21. http://ejournal.unida.ac.id.doi.org/ 10.30997/jsh.v3i1.351

Iskandar, A. (2020). Foreign Workers and Indonesia. Solid State Technology, 63 (2), 3824-3838. http://solidstatetechnology.us/

Ian, C. (1994). Modern Social Theory from Parsons to Habermas. Transleted to Indonesian Language by Paul S. Baut and T. Effendi from the original book [Teori Sosial Moderen], dari Parsons sampai Habermas]. 109-121, Jakarta, Manajemen PT, RajaGrafindo Persada.

Korten, D.C., \& Norman, T.U. (1981). Bureaucratic Reorientation For Participatory Rural Development. 15-22. National Association of Schools of Public Affairs and Administration, and Cornell University.

Mueller, D.J. (1992). Measuring Social Attitudes [Mengukur Sikap Sosial], Translated to Indonesian Language by Eddy Soewardi Kartawidjaja from the original book Measuring Social Attitudes. Jakarta, 11-26.Bumi Aksara.

Muhtamil, M. (2017). The Impact of Industrialization to the Absorbtion of Employeer in Jambi Province. Journal of Regional Financing and Development Perspectives, 4 (3), 199-206. https://doi.org/10.22437/ppd.v8i3.9868

Pratisto, A. (2004). The Easy Ways to Solve Problems of Statistics and Experimental Design with SPSS 12 [Cara Mudah Mengatasi Masalah Statistik dan Rancangan Percobaan dengan SPSS 12]. 83-84, Jakarta, PT. Elek Media Komputindo Publisher.

Passed, E. (2018). Eight Positive and Negative Effects of the Entry of Foreign Workers in Indonesia [Delapan Pengaruh Positif dan Negatif Masuknya Pekerja Asing di Indonesia]. https://tirto.id/nilai-passing-grade

Rakhmat, J. (2002). Communication Research Methods. [Metode Penelitian Komunikasi]. 82-83, Bandung, PT. Remaja Rosdakarya.

Sugiyono (2010). Statistics For Research [Statistik Untuk Penelitian]. 228-229, Bandung, Alfabeta

Sanderson, S.K. (1993). Macro Sociology [Sosiologi Makro]. Transleted to Indonesian Language by Farid Wajidi and S. Menno from the original book Macro Sociology, 85-102, Jakarta, RajaGrafindo Persada.

Wibawa, S. (2011). The Politics of Public Policy Formulation [Politik Perumusan Kebijakan Publik]. 1-2, Yogyakarta, Graha Ilmu.

Zilfiyah, S. (2013). Analysis of the Contribution of the Industrial Sector to the Absorption of Labor in the Industrial Sector in Indonesia for the Period of 2004-2010 (Thesis). Faculty of Economics and Business, Brawijaya University Malang, Brawijaya University Publisher. https://jimfeb.ub.ac.id/index.php/jimfeb/article/view/502

*** Central Bureau of Statistics (2019) [Badan Pusat Statistik (2019)]. About the Number of Unemployment in Indonesia. http//tirto.id/bps

*** Central Bureau of Statistics (2017) [Badan Pusat Statistik (2017)]. on Population and Poverty Lines in Bogor City. https://bogorkota. bps.go.id/subject/23/kemiskinan.html

***Central Bureau of Statistics (2019) [Badan Pusat Statistik (2019)]. Regarding Unemployment Data in Southeast Sulawesi. https://sultra.bps.go.id/news.html

*** Presidential Regulation Number 20. (2018). Foreign Workers and Indonesian Workers. https://jdih.kemnaker.go.id/data_puuE/20 _2018_Perpres_eng.pdf 